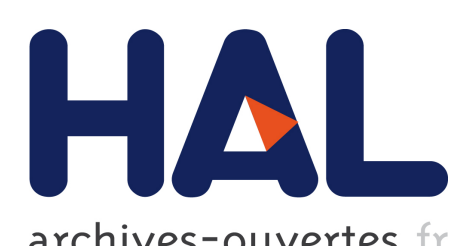

archives-ouvertes

\title{
How can a rare protected plant cope with the metal and metalloid soil pollution resulting from past industrial activities? Phytometabolites, antioxidant activities and root symbiosis involved in the metal tolerance of Astragalus tragacantha
}

\author{
Marie-Dominique Salducci, Hélène Folzer, Jacques Rabier, Julien Issartel, \\ Veronique Masotti, Pascale Prudent, Laurence Affre, Laurent Hardion, \\ Thierry Tatoni, Isabelle Laffont-Schwob
}

\section{To cite this version:}

Marie-Dominique Salducci, Hélène Folzer, Jacques Rabier, Julien Issartel, Veronique Masotti, et al.. How can a rare protected plant cope with the metal and metalloid soil pollution resulting from past industrial activities? Phytometabolites, antioxidant activities and root symbiosis involved in the metal tolerance of Astragalus tragacantha. Chemosphere, Elsevier, 2019, 217, pp.887 - 896. $<10.1016 /$ j.chemosphere.2018.11.078>. <hal-01926064>

\section{HAL Id: hal-01926064 \\ https://hal-amu.archives-ouvertes.fr/hal-01926064}

Submitted on 17 Jan 2019

HAL is a multi-disciplinary open access archive for the deposit and dissemination of scientific research documents, whether they are published or not. The documents may come from teaching and research institutions in France or abroad, or from public or private research centers.
L'archive ouverte pluridisciplinaire HAL, est destinée au dépôt et à la diffusion de documents scientifiques de niveau recherche, publiés ou non, émanant des établissements d'enseignement et de recherche français ou étrangers, des laboratoires publics ou privés. 
How can a rare protected plant cope with the metal and metalloid soil pollution resulting from past industrial activities? Phytometabolites, antioxidant activities and root symbiosis involved in the metal tolerance of Astragalus tragacantha

Marie-Dominique Salducci ${ }^{a}$, Hélène Folzer ${ }^{a}$, Julien Issartel ${ }^{a}$, Jacques Rabier ${ }^{a}$, Véronique Masotti ${ }^{a}$, Pascale Prudent ${ }^{b}$, Laurence Affre ${ }^{a}$, Laurent Hardion ${ }^{c}$, Thierry Tatoni ${ }^{a}$, Isabelle Laffont-Schwob $^{\text {a,d* }}$

${ }^{a}$ Aix Marseille Univ, Avignon Université, CNRS, IRD, IMBE, Institut Méditerranéen de Biodiversité et d'Ecologie marine et continentale, Marseille, France

${ }^{\mathrm{b}}$ Aix Marseille Univ, CNRS, LCE, Laboratoire de Chimie de l'Environnement, Marseille, France

${ }^{\mathrm{c}}$ Laboratoire Image Ville Environnement (LIVE), Université de Strasbourg, CNRS, Strasbourg, France

d Aix Marseille Univ, IRD, LPED, Laboratoire Population Développement Environnement, Marseille, France

* Corresponding author. Tel.: +33 413551230

E-mail address: isabelle.schwob@univ-amu.fr (I. Laffont-Schwob). 
Abstract

Astragalus tragacantha is a protected plant species in France that grows even in the trace metal and metalloid (TMM) polluted soils of the Calanques National Park (PNCal). Soils are mainly contaminated by lead, copper, zinc and arsenic. An ex situ experiment was conducted, firstly to determine the molecular responses and root traits involved in the TMM tolerance of this plant species by growing individuals in a soil from the surroundings of one of the brownfields of the PNCal, known as l'Escalette, where this plant species grows spontaneously. Secondly, in order to determine the plasticity of these responses, seeds were collected from three different populations, one at l'Escalette (polluted site), one from the Frioul archipelago (non-polluted, insular site) and one from La Seyne (non-polluted, littoral site). The results of this study confirmed the capacity of A. tragacantha to germinate and grow in TMM contaminated soils. Only moderate significant variations in chlorophyll and flavonol indices, proline content and antioxidant activities were detected between polluted and control soil conditions for all populations. The main driver for A. tragacantha TMM tolerance seemed to be its ability to be associated with root symbionts i.e. arbuscular mycorrhizal fungi and dark septate endophytes, corresponding to a nutrient-uptake strategy trait. This work provides support for the challenge of $A$. tragacantha conservation along the littoral of the PNCal, because increasing the number of $A$. tragacantha individuals would both increase vegetation cover of the polluted soils to reduce the pollution transfer and reinforce the populations of this species.

\section{Highlights}

A rare plant species able to grow in metal and metalloid contaminated soils

Germination and growth not affected by $\mathrm{Pb}$ and $\mathrm{As}$ soil pollution

High plasticity of seedlings of this rare protected plant 
Enhanced $\mathrm{Pb}$ and $\mathrm{As}$ tolerance due to nutrient-uptake strategy

Preserving this rare species may improve phytostabilization of soil pollutants

Keywords: heavy metals, proline, reactive oxygen species, plant growth, seed germination, root symbiosis 
Introduction

Trace metal and metalloid (TMM) contamination of soil, water and atmosphere is of worldwide concern (Mcintyre, 2003). One of the challenging issues is to better understand how the environment deals with these increasingly stressful conditions. The metallurgy industry in the past led to TMM pollution of surrounding soils. However, some brownfields are partially covered by spontaneous vegetation that probably developed several mechanisms of metal tolerance, enabling its survival in such a harsh environment. Therefore spontaneously vegetated brownfields provide a pool of TMM tolerant plant individuals healthy enough to maintain a self-sustaining population and also to enable us to refine in situ mechanisms of TMM tolerance. However, when a species establishes on a soil with high TMM content, plant tolerance to TMM will occur within the limits of phenotypic plasticity (Schat et al., 1997; Pollard et al., 2002; Ernst, 2006; Quintela-Sabarís et al., 2012).

In the literature, pseudo-metallophyte (i.e. facultative metallophyte) mainly refers to plants being able to grow both in TMM polluted and non-polluted areas (Tordoff et al., 2000; Sarret et al., 2002; Pauwels et al., 2006; Faucon et al., 2009; Marchiol et al., 2013; Favas et al., 2014). Due to TMM stress potentially reducing plant growth, results demonstrating no significant differences of growth of some pseudo-metallophytes between polluted and nonpolluted sites (Deram et al., 2006, Laffont-Schwob et al., 2011) contribute valuable information regarding their tolerance capacity and their ability to mitigate pollutant impacts. However, only considering plant occurrence or growth traits does not lead to identical responses, and raises questions regarding the ecological optimum of these pseudometallophytes (Faucon et al, 2011). Pseudo-metallophytes are known to have acquired specific TMM tolerance. However, the adaptation mechanisms may differ between metallophytes and pseudo-metallophytes (Baker et al., 2010; Pauwels et al., 2005; Pauwels et al., 2006). 
A typical consequence of TMM toxicity is the excessive production of reactive oxygen species (ROS) via Fenton-like reactions as singlet oxygen $\left({ }^{1} \mathrm{O}_{2}\right)$, superoxide radicals $\left(\mathrm{O}_{2} \cdot\right)$, hydrogen peroxide $\left(\mathrm{H}_{2} \mathrm{O}_{2}\right)$ and hydroxyl radicals $(\mathrm{OH})$ disturbing redox homeostasis (Shah et al., 2001; Mittler, 2002; Sharma et al., 2007; Mishra et al., 2011; Sharma et al., 2012). Furthermore, if ROS are not detoxified by endogenous mechanisms, oxidation of cellular compounds is likely to occur such as lipid peroxidation and alteration of protein/enzyme activity, resulting finally in plant death (Dubey, 2011; Hossain et al., 2012; Mediouni et al., 2009; Rascio and Navari-Izzo, 2011). In response, plants have developed various antioxidant defenses involving biomolecules (e.g. ascorbate, glutathione, tocopherol, proline), and enzymes (e.g. superoxide dismutases, peroxidases, catalases), which together constitute the total antioxidant capacity of cells (Larson, 1988; Ghisseli et al., 2000; Sytar et al., 2013). Proline commonly increases in plant tissues in response to environmental stresses (e.g. TMM, high salinity, drought, flooding, cold). However, besides its action as an osmolyte for osmotic adjustment, proline also contributes to stabilizing the sub-cellular structures (e.g. membranes and proteins) by scavenging free radicals and buffering cellular redox potential under stress conditions (Schat et al., 1997; Szabados and Savouré, 2009; Hayat et al., 2012).

Plant secondary metabolites are often referred to as molecules that play a major role in the adaptation of plants to their environment, notably by their involvement in defense mechanisms, and many key enzymes are involved in the biochemical detoxification of TMM (Baker and Whiting, 2002). Phenolic compound biosynthesis may be altered by TMM (Krupa et al., 1996; Zengin, 2006). However, an enhancement of phenylpropanoids can be observed under different stress conditions. These compounds may have an antioxidant action due to their ability to chelate metals (Sakihama et al., 2002). Phenolics possess hydroxyl and carboxyl groups, able to bind some metals such as copper. This increase in phenolics is correlated with increased activity of enzymes involved in the biosynthesis of phenols under 
heavy metal stress (Singh et al., 2016). Flavonoids, polyphenolic compounds from the phenylpropanoid pathway, may accumulate in epidermal cells of various plant organs (Sakihama et al., 2002). Therefore phenolic compounds may be good indicators of the health status of plant species under metal stress (Rabier et al., 2014).

Astragalus tragacantha L. (Fabaceae) is a western Mediterranean perennial cushionlike plant species well-adapted to drought. This endangered species is protected in France, where it is mainly distributed in the Calanques National Park (PNCal), Marseille (Hardion et al., 2010). In the PNCal, A. tragacantha populations are found to grow even in TMM polluted soils (Laffont-Schwob et al., 2011). These polluted soils are the heritage of the past industrial activity of the area, and in particular lead smelting (Daumalin and Laffont-Schwob, 2016). Major contaminants such as lead, copper, zinc and arsenic ( $\mathrm{Pb}, \mathrm{Cu}, \mathrm{Zn}$ and $\mathrm{As}$, respectively) were detected at high levels in the soils (Testiati et al., 2013; Affholder et al., 2013; Affholder et al., 2014), and in particular in the soils of the A. tragacantha habitat (Laffont-Schwob et al., 2011). Therefore A. tragacantha may be considered as a pseudo-metallophyte (Heckenroth et al., 2016). Literature on the metabolism of $A$. tragacantha is very scarce, and its potential ability for TMM phytostabilization, i.e. the use of plant cover aiming at reducing the mobility of contaminants of a soil, calls for a better understanding of the underlying mechanisms of this tolerance (Laffont-Schwob et al., 2011).

The aim of this study was to characterize the biochemical responses and root traits involved in the TMM tolerance of this plant species by growing individuals in a soil from the surroundings of the brownfield of l'Escalette, where this plant species grows spontaneously. The hypothesis is that root traits such as root symbioses may reveal a nutrient-uptake strategy under polluted conditions involved in A. tragacantha TMM tolerance. Secondly, to define the plasticity of these responses, seeds were collected from three different populations, and the 
potential effect of seed origin on the TMM tolerance was assessed through a laboratory experiment under controlled conditions.

\section{Materials and methods}

\section{Experimental design}

The seeds of Astragalus tragacantha were collected from different populations at three locations in the south of France (Fig. 1). Two of them are in the Calanques National Park (Marseille, France): one inland at l'Escalette (ESC), the second in the Frioul archipelago (FRI) at Pomègues island, and the third along the coast at La Seyne (VAR), Var, France (Fig. 1). These three disconnected populations were chosen to test the hypothesis of a plant response plasticity to TMM exposure, since it has been previously demonstrated by Hardion

et al. (2016) that fragmentation of the A. tragacantha populations is a driver of its diversification.

The A. tragacantha seeds from the l'Escalette populations (ESC) come from a polluted environment with a highly TMM contaminated soil due to its industrial heritage. The Frioul population (FRI) is found on a non-agronomic soil without industrial heritage, and the La Seyne population (VAR), on a small cliff. Soils of the latter two populations are less anthropized and contaminated, thus allowing a comparative approach for the effect of soils and seeds origins on the $A$. tragacantha growth. For each population, five individuals were randomly selected at least $5 \mathrm{~m}$ apart from each other. Fifty seeds were collected (roughly) from each individual, then stored in a dry/dark place until use for the experiment.

To characterize the edaphic in situ conditions before collection, a composite sample of soil taken at four points around each plant $(\leq 15 \mathrm{~cm}$ topsoil) was collected under the same five 
A. tragacantha individuals at each seed collection site, and pooled in a single soil sample considered as representative of soil composition for the whole population, and analyzed by portable X-ray fluorescence analyzer (Niton ${ }^{\circledR}$ XLt $792 \mathrm{~W}$, Thermo Scientific). The polluted soil for the laboratory experiment was collected at the brownfield of l'Escalette, air-dried at room temperature and sieved at $2 \mathrm{~mm}$ before analysis and use. The experimental design of soil collection, treatment and analysis is detailed in Figure 1, the results of analyzed elements in soil samples such as $\mathrm{Pb}, \mathrm{As}, \mathrm{Zn}$ and $\mathrm{Cu}$ are presented in Table 1.

\section{Soil composition for plant culture under controlled conditions}

Two different soils were used for the experiment i.e. one polluted and another nonpolluted. As a control of unpolluted soil, commercial loam (STM, terreau semis compatible AB, Botanic ${ }^{\circledR}$, France) was used. The TMM composition of this control loam obtained by portable X-ray fluorescence analyzer (Niton ${ }^{\circledR}$ XLt 792W, Thermo Scientific) is detailed in Table 1.

The polluted soil used in the lab experiment comes from the brownfield of l'Escalette. Soil samples (2.51 per plot) were randomly collected at five plots in the top $15 \mathrm{~cm}$-layer (after removal of the litter) in the brownfield in proximity to the A. tragacantha population and pooled by mixing an equal weight from each plot. The obtained composite soil (SPO) was sieved at $2 \mathrm{~mm}$ in in situ. Then for TMM analyses, an aliquot of the composite soil was airdried at room temperature and ground (RETSCH zm 1000 with tungsten blades and titanium sieve) to $0.2 \mathrm{~mm}$. It was mineralized in a microwave mineralizer (Milestone Start D) using aqua regia $\left(1 / 3 \mathrm{HNO}_{3}+2 / 3 \mathrm{HCl}\right)$, then filtered with a $0.45 \mu \mathrm{m}$ mesh. TMM levels were determined by ICP-AES (Jobin Yvon Horiba, Spectra 2000) for Zn, Cu and Pb (Affholder et al, 2013), and by graphite furnace AAS (Thermo Scientific ICE 3000) for As (3 analytical replicates). Quality assurance-quality controls and accuracy were checked using standard soil 
reference materials (CRM 049-050, from RTC-USA), with accuracies within $100 \pm 10 \%$. The TMM composition of this polluted soil is detailed in Table 1.

\section{Seeding and plant growth conditions and growth parameters}

Due to its protection status, experiments on A. tragacantha were conducted under controlled conditions with seedlings. For each population (ESC, VAR, FRI), seeds collected in the wild were scarified with a piece of sandpaper, and then placed in pots in environmental test chambers (MLR-351H, Sanyo), four seeds per pot. For each population, five replicates were grown on SPO soil ( $70 \%$ contaminated soil sieved at $2 \mathrm{~mm}+30 \%$ washed sand) in 200 ml-individual pots, and five replicates were grown on STM soil (70\% commercial loam + $30 \%$ washed sand) in $200 \mathrm{ml}$-individual pots, for a total of 30 pots. The pots were watered twice a week with deionized water at constant mass to maintain almost constant soil moisture during the experiment (60\% water holding capacity). Plants were grown during ca. 5 months

under a photon flux density of $150 \mu \mathrm{mol} . \mathrm{m}^{-2} \mathrm{~s}^{-1}$, photoperiod of $16 \mathrm{~h}$ at $25^{\circ} \mathrm{C}$ and nyctiperiod of $8 \mathrm{~h}$ at $15^{\circ} \mathrm{C}$ with a constant rate of humidity of $60 \%$. Seed germination percentages were determined 1 and 3 weeks after sowing. Shoot height and leaf number were monitored after 3, 6 and 21 weeks.

At the end of the experiment, root and shoot parts were harvested separately. Root parts were washed carefully (to remove any substrate particles) under tap water and rinsed three times with deionized water. A root sample of each individual was kept in ethanol $\left(60^{\circ}\right)$ for root symbiosis observation. Root and shoot parts were weighed and their maximum lengths measured, and then root and shoot samples were frozen in liquid nitrogen and kept at $80^{\circ} \mathrm{C}$ until biochemical analysis.

\section{Non-destructive phytometabolites monitoring with Multiplex}


Monitoring of phytometabolites was done after 3, 6 and 21 weeks during the experiment. Plant health status was determined with a portable fluorimeter Multiplex® 3 (FORCE-A, Orsay, France) through the estimation of simultaneous measurements of epidermal phenol, flavonol, anthocyanin and chlorophyll indices, and a N/C index (Rabier et al., 2014). Non-destructive measurements with Multiplex equipment are based on the chlorophyll fluorescence screening method (Agati et al., 2007; Cerovic et al., 2008; Agati et al., 2011) and different combinations of the blue-green, red and far-red fluorescence signals at the various excitation bands could be used as indices of the different compounds. For each condition (SPO and STM), five measurements were made on each replicate per population (for a total of 15 measurements per soil condition). Phytometabolite indices were expressed as an average value per population, and soil condition of five replicates (mean values of 5 measurements per individual).

\section{Plant bioassays}

Root and shoot frozen samples collected at the end of the controlled culture experiment from each population and soil condition were used. Total antioxidant capacity and lipid peroxidation were estimated on these samples (5 replicates).

\section{Lipid peroxidation assay (MDA)}

The amount of lipid peroxidation was estimated with TBARS (Thiobarbituric Acid Reactives Substances) Assay Kit, from Cayman Chemical Company. Frozen roots and shoot were individually mashed under high-speed shaking in a Tissue Lyser (Retsch, Haan, Germany) during $1 \mathrm{~min}$ at $30 \mathrm{~Hz}$ three times with stainless steel beads in $1.5 \mathrm{ml}$ of extraction buffer $\left(5 \mathrm{mM} \mathrm{KH}_{2} \mathrm{PO}_{4}\right.$, pH 7.4 with $0.9 \% \mathrm{NaCl}$ and $0.1 \%$ glucose $)$. Root samples were supplemented with driselase 1\% (Sigma, CAS Number 85186-71-6). The resulting 
homogenates were centrifuged at $1600 \mathrm{xg}$ for $10 \mathrm{~min}$ at $4^{\circ} \mathrm{C}$, and $100 \mu 1$ supernatant aliquots was sampled and stored at $-80^{\circ} \mathrm{C}$ until the experiment.

Samples were then prepared with $100 \mu$ of root or shoot samples or standard malondialdehyde (MDA), and homogenized with $100 \mu \mathrm{l}$ of SDS solution and $4 \mathrm{ml}$ of the color reagent (Tella et al., 2014). The reaction mixture was heated at $100^{\circ} \mathrm{C}$ for $60 \mathrm{~min}$ in a water bath and cooled immediately in ice for $10 \mathrm{~min}$, and then centrifuged at $1600 \mathrm{xg}$ for 10 min at $4^{\circ} \mathrm{C}$. Finally, MDA content of the supernatant was determined spectrophotometrically (BioTek Epoch, Winooski, VT, USA) at $\mathrm{A}_{530 \mathrm{~nm}}$ and compared to a MDA standard curve. TBARS contents were normalized to total protein content, which was determined at $595 \mathrm{~nm}$ by the Bradford method (Bradford, 1976), using bovine serum albumin (BSA) as standard.

\section{Total antioxidant capacity (TAOC)}

Total antioxidant content in the different organs (root and shoot) was determined according to Miller et al. (1993), using the antioxidant Assay Kit (ABTS method) from Cayman Chemical Company. Samples were prepared following the same method as for lipid peroxidation measurement. The resulting homogenates were centrifuged at $10000 \mathrm{x} g$ for 15 min at $4{ }^{\circ} \mathrm{C}$, and $80 \mu 1$ of the supernatant were sampled and stored at $-80^{\circ} \mathrm{C}$ until the TAOC measurements.

The assays (triplicate) were prepared on 96-well plates with $10 \mu 1$ of Trolox (standard) or $10 \mu \mathrm{l}$ of samples, $10 \mu \mathrm{l}$ of metmyoglobin and $150 \mu \mathrm{l}$ of chromogen. Reactions were initiated by adding $40 \mu \mathrm{l}$ hydrogen peroxide. The plate was then incubated at room temperature under agitation during $5 \mathrm{~min}$. Absorbance was spectrophotometrically determined at $750 \mathrm{~nm}$ and total antioxidant content was calculated by comparison with a Trolox (a watersoluble tocopherol analogue) standard curve. As for the TBARS, TAOCs were normalized to total protein, which was determined according to the Bradford method (Bradford, 1976). 


\section{Proline assay}

Proline was extracted as described by Abraham et al. (2010). Approximately $200 \mathrm{mg}$ of frozen tissues of shoots or roots were ground in nitrogen liquid in a mortar and centrifuged with $3 \%$ aqueous sulfosalicylic acid solution ( $5 \mu \mathrm{l} / \mathrm{mg}$ fresh weight) at $2000 \mathrm{x}$ g for $5 \mathrm{~min}$. $100 \mu \mathrm{l}$ of plant supernatant extract were added to glacial acetic acid $(200 \mu \mathrm{l})$, ninhydrin reagent $(200 \mu \mathrm{l})$ and $3 \%$ sulfosalicylic acid $(100 \mu \mathrm{l})$ mix. The tubes were incubated at $96^{\circ} \mathrm{C}$ for $60 \mathrm{~min}$ and the reaction was stopped in ice. After addition of toluene $(2 \mathrm{ml})$ to the reaction mixture, samples were vortexed $20 \mathrm{sec}$ and incubated $5 \mathrm{~min}$ at room temperature. The absorbance of the chromophore containing toluene was measured at a wavelength of $520 \mathrm{~nm}$ using toluene as reference. The proline concentration is determined using standard concentration curve and calculated on fresh weight $\left(\mu \mathrm{mol} . \mathrm{g}^{-1} \mathrm{FW}\right)$ basis, as follows (Bates et al., 1973):

$(\mu$ moles proline $/ \mathrm{g}$ of fresh weight $)=\frac{[(\mu \mathrm{g} \text { of proline } / \mathrm{ml} \mathrm{x} \mathrm{ml} \mathrm{toluene}) /[115.5 \mu \mathrm{g} / \mu \mathrm{mole}]}{[\mathrm{g} \text { sample } / 5]}$

\section{Root symbiont observations}

For each treatment, root samples stored in alcohol $\left(60^{\circ}, \mathrm{v} / \mathrm{v}\right)$ were rinsed and cut into 10 segments $1 \mathrm{~cm}$-long per replicate (total of 50 root segments per condition). The root segments were cleared by boiling in $10 \% \mathrm{KOH}$ (between 5 and $10 \mathrm{~min}$ ), and then rinsed several times under tap water. The cleared roots were boiled for $3 \mathrm{~min}$ in $5 \%$ ink (Pelikan)/white vinegar solution according to Vierheilig et al. (1998). The percentage of root symbioses was estimated by visual observations of fungal structures: vesicles, arbuscules and intraradical hyphae for arbuscular mycorrhizal (AM) symbionts and microsclerotia and septate mycelia for dark septate endophytes (DSE). For each kind of symbiont, results were expressed as a percentage of symbiont colonization of root length. 


\section{Statistical analysis}

Statistical analyses were performed for all data using JMP 10 statistical software (SAS Institute, Cary, North Carolina, USA). Differences between the two soil conditions (SPO and STM), and between the three populations (ESC, VAR, FRI) for all plant growth parameters, plant stress indices and, root symbionts, were determined using the nonparametric Wilcoxon test at $p \leq 0.05$, and Dunn's test pairwise comparisons was used as post-hoc test at $p \leq 0.05$. A principal component analysis was done with the biochemical and root-traits data for the three populations and the two soil conditions.

\section{Results}

\section{Soil analyses}

The composite soil (SPO) used for the controlled condition culture experiment was highly contaminated by $\mathrm{Pb}$ and As (Table 1), with up to 170-fold more contaminated with $\mathrm{Pb}$ and up to 45-fold with As than the less anthropized soils of FRI and VAR A. tragacantha populations, and 3-fold more contaminated with $\mathrm{Pb}$ and 6-fold with As than the soil from the Escalette population (ESC). Contamination factors (average TMM soil concentration on a site / average TMM concentration of the local background) could be calculated from an estimation of the local contamination background levels in soils of the PNCal area (43, 5, 7.5 and 66 mg.kg ${ }^{-1}$ for $\mathrm{Pb}, \mathrm{As}, \mathrm{Cu}$ and $\mathrm{Zn}$, respectively (Affholder et al., 2014)). They presented values of 71 and 215 for $\mathrm{Pb}, 34$ and 225 for $\mathrm{As}, 25$ and 41 for $\mathrm{Zn}$ in ESC and SPO, respectively, while contamination factor values were between 2 and 4 for FRI whatever the element. Local contamination background is not available for the La Seyne area (VAR), so contamination factors could not be calculated for the soils of this population. But TMM 
concentrations in these soils were similar to FRI for $\mathrm{As}$ and $\mathrm{Cu}$, and lower than FRI for $\mathrm{Pb}$ and $\mathrm{Zn}($ Table 1).

\section{Germination rate}

For the ESC population, no significant differences of germination rate were found between STM and SPO soil conditions after 1 and 3 weeks (Fig. 2). For the FRI population, no significant differences were observed after 1 week between STM and SPO soil conditions. However, germination rate was higher in SPO soil than STM after 3 weeks. For the VAR population, germination rate was higher in SPO soil than STM after 1 week, but this difference disappeared after 3 weeks. The highest germination rate was obtained for the ESC population. Furthermore, the germination rate for ESC was significantly higher in STM condition than those for the FRI and VAR populations (Fig. 2). Maximum germination rates were obtained after 3 weeks for each condition.

\section{Growth traits and root symbiont occurrence of $A$. tragacantha depending on soil conditions and seed origin}

After 3 and 6 weeks of growth, no significant differences of growth were revealed between populations (ESC in highly contaminated soil vs FRI, VAR, in soils without industrial heritage) nor soil (SPO, STM) condition (Fig. 2). However, after 21 weeks of culture, seedlings from ESC and FRI had a significantly lower shoot height than the seedlings from VAR in the SPO condition, whereas no significant differences of shoot height were observed between all populations in the STM soil after the same time. Comparing the same population in both soil conditions, a significant difference was observed only for the seedlings from FRI, i.e. individuals in the STM soil had a significantly greater, height than those in the SPO soil, and stunting in shoot length was ca. $23 \%$ after 21 weeks of culture. 
Whatever the population and the soil condition, no significant differences of root length were observed after 21 weeks of culture (Fig. 3). Concerning root symbionts, arbuscular mycorrhizal (AM) fungi and dark septate endophytes (DSE) were observed in all root systems whatever the population or the soil condition. However, occurrence of AM mycelium was significantly higher in SPO condition than in STM condition, and percentage of AM vesicle was significantly higher in SPO condition compared to STM condition for ESC and VAR, respectively. No significant differences were observed for the DSE occurrence whatever the population or the soil condition.

\section{TMM tolerance mechanisms of A. tragacantha depending on soil condition and} seed origin

The monitoring of primary and secondary metabolites using non-destructive equipment was done after 3, 6 and 21 weeks (Fig. 4). After 3 weeks, the chlorophyll index was significantly higher for SPO than STM condition for FRI and VAR seedlings. However, in the STM condition, this index was significantly higher for ESC seedlings than for VAR seedlings at the same time. After 6 weeks, this index was still significantly higher for SPO than STM condition only for VAR seedlings. After 21 weeks, the chlorophyll index was significantly higher for SPO than STM condition for ESC seedlings. The main tendency is thereafter that this index was mostly higher for individuals grown under stressful conditions (SPO) than in the control condition (STM), whatever their origin.

The flavonol index was too low after 3 weeks to lead to any conclusion. Values of flavonol index increased from 3 weeks of culture to 21 weeks This index was significantly higher for SPO than STM condition for FRI and VAR seedlings, respectively, after 6 weeks following the same frame as the chlorophyll index at 3 weeks. After 21 weeks, this index was higher than before, but no significant differences could be observed any longer between soil 
conditions, whatever the population. The phenol (a global index of phenolic compounds) and NBI (representing the balance between $\mathrm{C}$ and $\mathrm{N}$ storage) indices did not significantly differ between soil conditions, whatever the population and the time of observation.

At the end of the experiments (i.e. after 21 weeks), contents of proline, lipid peroxidation (TBARS) and total antioxidant capacity (TAOC) were determined in the shoot and root systems, separately (Fig. 5). Amongst all the monitored parameters, only proline in root samples and TBARS content significantly varied both in root and shoot samples between STM and SPO conditions. However, considering each population separately, only proline content in roots was significantly higher in SPO than STM condition for ESC and VAR seedlings.

The principal component analysis done with the biochemical and root-traits data for the three populations and the two soil conditions (Fig. 6) revealed that $46.7 \%$ of the variance for the data was accounted for by the different physiological and morphological traits in two components. In component 1 , the root symbiosis percentages segregated STM from SPO conditions, and in component 2, N/C balance (NBI index) segregated FRI from VAR populations since ESC population responses were more diffuse.

\section{Discussion}

The results of this study confirmed the capacity of $A$. tragacantha to germinate and grow in TMM contaminated soils, in agreement with a previous study (Laffont-Schwob et al., 2011). In addition, Affholder et al. (2014) suggest that arbuscular mycorrhizal (AM) fungi and dark septate endophytes (DSE) associated with the roots of native Rosmarinus officinalis individuals contribute to their TMM tolerance in the same pollution context in the Calanques National Park. This hypothesis was also previously suggested for A. tragacantha (LaffontSchwob et al., 2011). The results of this study confirmed the important role of root symbionts 
in the TMM tolerance. Rozpądek et al (2014) demonstrated that in Cichorium intybus subjected to trace metal soil pollution, occurrence of symbiotic fungi in root systems creates a new redox homeostasis, enabling this species to cope with the deleterious effects of metal toxicity.

\section{Hypothesis regarding the $A$. tragacantha nutrient-uptake strategy under polluted conditions}

The common effects of stress induced by soil pollution are reduced growth, leaf chlorosis and alteration of activity of many key enzymes of metabolic pathways (Singh et al., 2016). This plant growth reduction is due to disturbance of nutrients and water uptake, and to secondary stresses such as oxidative stress (Sytar et al., 2013). Arbuscular mycorrhizal (AM) fungi and dark septate endophytes (DSE) have the capacity of enhancing plant growth and nutrient uptake in heavy metal polluted soils (Ma et al., 2016a). Regarding shoot height, only FRI seedlings appeared affected by the pollution. This population originates from an island near Marseille, and is isolated from any sources of industrial pollution. Surprisingly, VAR seedlings originating from a non-TMM polluted area appeared not to be affected by the soil pollution with regard to their growth. In a previous study on the morpho-colorimetric variability of seeds of $A$. tragacantha (Grillo et al., 2013), the highest variability was observed for seeds from Les Goudes, which is a population located near the ESC population, also known as a highly TMM-contaminated site (Laffont-Schwob et al., 2016). In our work, we hypothesized that the selection of three disconnected populations i.e. two in the PNCal on calcareous soils (ESC and FRI), and the third from a more acidic soil (VAR), would provide a high genetic diversity of responses to TMM exposure. This would mean an occurrence of potential edaphic types of this pseudo-metallophyte with various levels of TMM tolerance, as a form of local adaptation, as described by Pauwels et al. (2005). Our results did not enable 
such a distinction with similar biochemical responses. However, TMM tolerance has been demonstrated in Arabidopsis halleri populations that have not experienced metal exposure (Pauwels et al., 2006), corroborating that the FRI and VAR populations are as TMM tolerant as the ESC population. We hypothesized therefore that an important driver for A. tragacantha TMM tolerance is the ability of this plant species to be associated with root symbionts, and corresponds to a nutrient-uptake strategy trait sensu Cornelissen et al. (2003), corresponding to various adaptations developed by plants to acquire phosphorus and nitrogen. Moreover, mycorrhizal fungi and dark septate endophytes may provide host plants with access to nitrogenous and phosphorous reserves via specific transporters (Behie and Bidochka, 2014). In our study, roots of $A$. tragacantha seedlings were colonized by AM fungi and DSE, whatever the population or the soil condition. It has been previously proven that arbuscular mycorrhizal (AM) fungi and dark septate endophytes (DSE) have the capacity of enhancing plant growth and nutrient uptake in heavy metal polluted soils, or by conferring plant metal tolerance (Ma et al., 2016a; Ma et al., 2016b; Kong and Glick, 2017; Becerra-Castro et al., 2012). Similarly, it can be hypothesized that the occurrence of these associated microorganisms plays a key role in A. tragacantha metal tolerance. Comparing the major parameters monitored, a main driver to distinguish individuals grown in the polluted soil (SPO) from those grown in the control soil (STM) was the AM colonization (mycelium and vesicle percentages, cf Fig. 2). Gucwa-Przepióra et al. (2016) demonstrated in Plantago lanceolata and $P$. major a high tolerance to metals associated with a well-functioning mycorrhizal symbiosis observed in phytotoxic soil conditions.

\section{TMM tolerance mechanisms of $A$. tragacantha}

Even if no phenotypical variations are distinguishable, TMM may alter plant metabolism, inhibiting, for example, phenylalanine ammonia-lyase (PAL), enzymes 
regulating the phenylpropanoid pathway involved in phenolic compounds synthesis such as flavonols (Krupa et al., 1996). Molecular responses of $A$. tragacantha showed a TMM tolerance of this plant species, involving primary (chlorophylls) and secondary (phenolics) metabolites. The chlorophyll and flavonol indices were mostly higher (cf Fig. 6) for the individuals grown under the stressful conditions (SPO) than the control ones (STM). However, none of the evaluated biomarkers of stress, i.e. proline, lipid peroxidation and antioxidant defenses, significantly varied in shoot parts comparing SPO and STM for each population separately. Our results are in agreement with those published by Tapia et al. (2013), who found higher concentrations of chlorophyll in shoot of Atriplex atacamensis and Atriplex halimus exposed to arsenic pollution. The same authors also showed no significant difference in lipid peroxidation between polluted and control soil in A. atacamensis leaves, and similarly in A. tragacantha shoots.

The roots of $A$. tragacantha act as the first contact interface with soil pollution. In most cases, in contaminated soils, higher proline contents were accumulated by roots in contaminated soils compared to proline levels accumulated in control soils. Accordingly, the synthesis of this specific amino acid may be important for defense mechanisms against oxidative stress induced by TMM occurrence in soil (Sharma and Dietz, 2006).

\section{Potential influence of seed origin on $A$. tragacantha TMM tolerance}

The highest germination rates were obtained for seeds from the ESC population. For the FRI population, the higher germination rate in the SPO condition appeared to be delayed compared to the VAR population. The germination rates varied from $43 \%$ to $90 \%$. Heavy metals may alter seed germination (Singh et al., 2016). A delay in germination is also observed between contaminated and non-contaminated soils for Silene vulgaris (Wierzbicka and Panufnik, 1998). 
A previous paper concerning the comparison of seed provenances across various environments showed that the origin of seeds may have a significant impact on the success of restoration for four plant species i.e. Legousia speculum-veneris, Echium vulgare, Cichorium intybus and Origanum vulgare (Bischoff et al., 2006). Grillo et al. (2013) indicated that the geographical isolation of $A$. tragacantha populations may be a driver for its high intra-specific variability. However, our results regarding seed adaptability to TMM in soils could not be directly connected to genetic variability. Moreover, other authors (Hardion et al., 2016) suggested that $A$. tragacantha diversification is connected to the fragmentation of the populations and not to a coastal-to-mountain ecological shift. Faucon et al. (2011) developed an interesting concept regarding certain rare pseudo-metallophytes that may colonize recent anthropogenic habitats due to their high plasticity. These authors suggest that such recently altered habitats may have a conservation value for these rare pseudo-metallophytes. Accordingly, we may support the idea that the TMM contaminated littoral soils of the Calanques National Park, resulting from recent past industrial activities (mid-19 ${ }^{\text {th }}$ to early $20^{\text {th }}$ century), may be a suitable habitat for A. tragacantha reinforcement or reintroduction.

\section{Conclusion}

This paper is the first dealing with the ecophysiology of the rare protected plant species A. tragacantha, leading to a better understanding of its capacity to persist on TMM contaminated soils in its distribution area. This work consolidates the challenge of $A$. tragacantha conservation along the littoral of the Calanques National Park, by increasing the vegetation cover of the polluted soils to reduce soil erosion and the vegetation establishment i.e. increasing the number of $A$. tragacantha individuals. Concomitantly, from the conservation and phytostabilisation point of view, a map of the soil TMM contamination in the PNCal could be overlapped with the distribution of the potential habitat of this endangered 
species in order to designate suitable sites for both phytostabilisation and population reinforcement.

\section{Acknowledgements}

The authors are grateful to Faivre A., Raffin J., Saunier A. and Gay L. for their help in growth measurements and biochemical analyses. Many thanks to Dumas P.-J. for seed collection in the Marseille area. This study was funded by the French Research National Agency (ANR Marséco 2008 CESA 018), and financially supported by the National Innovative Cluster on Risks Management. Many thanks to the Calanques National Park, and particularly to Le MirePécheux L. , for advice and authorization for seed and soil harvesting, and to Michael Paul for English proofreading of the paper. 


\section{References}

Ábráham, E., Hourton-Cabassa, C., Erdei, L., and Szabados, L., 2010. Methods for determination of proline in plants, in: Sunkar, R (ed.), Plants Stress Tolerance. Springer, London Methods in Molecular Biology 639, pp 317-331.

Affholder, M.C., Prudent, P., Masotti, V., Coulomb, B., Rabier, J., Nguyen-The, B., LaffontSchwob, I., 2013. Transfer of metals and metalloids from soil to shoots in wild rosemary (Rosmarinus officinalis L.) growing on a former lead smelter site: human exposition risk. Sci. Total. Environ. 454-455, 219-229.

Affholder, M.C., Pricop, A.D., Laffont-Schwob, I., Coulomb, B., Rabier, J., Borla, A., Demelas, C., Prudent, P., 2014. As, Pb, Sb and $\mathrm{Zn}$ transfers from soil to root of wild rosemary: do native symbionts matter? Plant. Soil. 382, 219-239.

Agati, G., Matteini, P., Goti, A., Tattini, M., 2007. Chloroplast-located flavonoids canscavenge singlet oxygen. New Phytol 174, 77-89.

Agati, G., Cerovic, Z.G., Pinelli, P., Tattini, M., 2011. Light-induced accumulation of orthodihydroxylated flavonoids as non-destructively monitored by chlorophyll fluorescence excitation techniques. Environ. Exp. Bot. 73, 3-9.

Baker, A.J.M., Whiting, S.N., 2002. In search of the Holy Grail - a further step in understanding metal hyperaccumulation. New Phytol. 155, 1-4.

Baker, A.J.M., Ernst, W.H.O., Van Der Ent, A., Malaisse, F., Ginocchio, R., 2010. Metallophytes: the unique biological resource, its ecology and conservational status in Europe, central Africa and Latin America, in: Batty, L.C., Hallberg, K.B. (Eds.), Ecology of Industrial Pollution. Cambridge University Press, pp. 21-40.

Bates, L.S., Waldren, R.P., Teare, I.D., 1973. Rapid determination of free proline content for water-stress studies. Plant. Soil. 39, 205-207. 
Becerra-Castro, C., Monterroso, C., Prieto-Fernández, A., Rodríguez-Lamas, L., LoureiroViñas, M., Acea, M.J., Kidd, P.S., 2012. Pseudometallophytes colonising Pb/Zn mine tailings: A description of the plant-microorganism-rhizosphere soil system and isolation of metaltolerant bacteria. J. Hazard. Mat. 30, 217-218.

Behie, S.W., Bidochka, M.J., 2014. Nutrient transfer in plant-fungal symbioses. Trends Plant Sci. Nov 19(11), 734-740.

Bischoff, A., Vonlanthen, B., Steinger, T., Müller-Schärer, H., 2006. Seed provenance matters - Effects on germination of four plant species used for ecological restoration. Basic. Appl Ecol. 7, 347-359.

Bradford, M.M., 1976. A rapid and sensitive method for the quantification of microgram quantities of protein utilizing the principle of protein-dye binding. Anal. Biochem. 72, 248.

Cerovic, Z.G., Moise, N., Agati, G., Latouche, G., Ben Ghozlen, N., Meyer, S., 2008. New portable optical sensors for the assessment of winegrape phenolic maturity based on berry fluorescence. J. Food. Compos. Anal. 21, 650-654.

Cornelissen, J.H.C., Cerabolini, B., Castro-Díez P., Villar-Salvador P., Montserrat-Martí, G., Puyravaud, J.P., Maestro, M.,Werger, M.J.A., Aerts, R., 2003. Functional traits of woody plants: correspondence of species rankings between field adults and laboratory-grown seedlings? J. Veg. Sci.14, 311-322.

Daumalin, X., Laffont-Schwob, I., 2016. Les Calanques industrielles de Marseille et leurs pollutions. Une histoire au présent, REF.2C editions pp 336.

Deram, A., Denayer, F.O., Petit, D., Van Haluwyn, C., 2006. Seasonal variations of cadmium and zinc in Arrhenatherum elatius, a perennial grass species from highly contaminated soils. Environ. Pollut. 140, 62-70. 
Dubey, R.S., 2011. Metal toxicity, oxidative stress and antioxidative defense system in plants, in: Gupta S.D., (Ed), Reactive Oxygen Species and Antioxidants in Higher Plants. CRC Press, Boca Raton, Fla, USA, pp. 177-203.

Ernts, W.H.O., 2006. Evolution of metal tolerance in higher plants. For. Snow. Landsc. Res. $80(3), 251-274$.

Faucon, M.P., Colinet, G., Mahy, G., Ngongo Luhembwe, M., Verbruggen, N., Meerts, P., 2009. Soil influence on $\mathrm{Cu}$ and $\mathrm{Co}$ uptake and plant size in the cuprophytes Crepidorhopalon perennis and C. tenuis (Scrophulariaceae) in SC Africa. Plant Soil. 317, 201-212.

Faucon, M. P., Parmentier, I., Colinet, G., Mahy, G., Ngongo Luhembwe, M., Meerts, P., 2011. May Rare Metallophytes Benefit from Disturbed Soils Following Mining Activity? The Case of the Crepidorhopalon tenuis in Katanga (D. R. Congo). Restor Ecol. 19 (3), 333-343.

Favas, P.J.C., Pratas, J., Varun, M., D'Souza, R., Paul, M.S., 2014. Phytoremediation of Soils Contaminated with Metals and Metalloids at Mining Areas: Potential of Native Flora, in: Hernandez-Soriano, M.C. (Eds.), Environmental Risk Assessment of Soil Contamination. InTech, Rijeka, Croatia, pp. 485-517.

Ghisseli, A., Serafini, M. F., Scaccini, C., 2000. Total antioxydant capacity as a tool to assess redox status: critical view and experimental data. Free Radical. Biol. Med. 29, 1106-1114.

Grillo, O., Mattana, E., Fenu, G., Venora, G., Bacchetta, G.,2013. Geographic isolation affects inter- and intra-specific seed variability in the Astragalus tragacantha complex, as assessed by morpho-colorimetric analysis. C.R. Biol. 336, 102-108.

Gucwa-Przepióra, E. Nadgórska-Socha, A. ; Fojcik, B. ; Chmura, D. 2016. Enzymatic activities and arbuscular mycorrhizal colonization of Plantago lanceolata and Plantago major in a soil root zone under heavy metal stress. Environ. Sci. Pollut. Res. 23, 4 742-4 755.

Hardion, L., Baumel, A., Dumas, P.J., Duong, N., Affre, L., Tatoni, T., 2010. Phylogenetic 
relationships and infrageneric classification of Astragalus tragacantha L. (Fabaceae), inferred from nuclear ribosomal DNA Internal transcribed spacers data (nrDNA ITS). Ecol. Mediterranea. 36, 99-106.

Hardion, L., Dumas, P.J., Abdel-Samad, F., Bou Dagher Kharrat, M., Surina, B., Affre L., Médail, F., Bacchetta, G., Baumel, A., 2016. Geographical isolation caused the diversification of the Mediterranean thorny cushion-like Astragalus L. sect. Tragacantha DC. (Fabaceae). Mol Phylogenet Evol. 97, 187-195.

Hayat, S., Hayat, Q., Alyemeni, M.N., Wani, A.S., Pichtel, J., Ahmad, A., 2012. Role of proline under changing environments: a review. Plant. Signal. Behav. 7(11), 1456-1466.

Heckenroth, A., Rabier, J., Dutoit, T., Torre, F., Prudent, P., Laffont -Schwob, I., 2016. Selection of native plants with phytoremediation potential for highly contaminated Mediterranean soil restoration: tools for a non-destructive and integrative approach. J. Environ. Manage. 183, 850-863.

Hossain, M.A., Piyatida, P., Teixeira da Silva, J.A., Fujita, M., 2012. Molecular Mechanism of Heavy Metal Toxicity and Tolerance in Plants: Central Role of Glutathione in Detoxification of Reactive Oxygen Species and Methylglyoxal and in Heavy Metal Chelation. J. Bot. 1-37.

Kong, Z., Glick B.R., 2017. The role of plant growth-promoting bacteria in metal phytoremediation. Adv Microb Physiol, 71, 97-132.

Krupa, Z., Baranowska, M., Orzol, D., 1996. Can anthocyanins be considered as heavy metal stress indicator in higher plants? Acta Physiol Plant. 18, 147-51.

Laffont-Schwob, I., Dumas, P.J., Pricop, A., Rabier, J., Miché, L., Affre, L., Masotti, V., Prudent, P., and Tatoni, T., 2011. Insights on metal-tolerance and symbionts of the rare species Astragalus tragacantha aiming at phytostabilization of polluted soils and plant conservation. Ecol. Mediterranea. 37, 57-62. 
Laffont-Schwob, I., Heckenroth, A., Rabier, J., Masotti, V., Oursel, B., Prudent, P., 2016. Une pollution présente diffuse et étendue. In: Daumalin X. \& Laffont-Schwob I. Les Calanques marseillaises industrielles : une histoire au présent, Ed. REF2C, pp. 204-249.

Larson, R.A., 1988. The antioxydants of higher plants. Phytochem. 27, 969-978.

Ma, Y., Oliveira, R.S., Freitas, H., Zhang, C.,2016a. Biochemical and Molecular Mechanisms of Plant-Microbe-Metal Interactions: Relevance for Phytoremediation. Front Plant Sci. 7 (918), 1-19.

Ma, Y., Raikumar, M., Zhang, C., Reitas, H., 2016b. Beneficial role of bacterial endophytes in heavy metal phytoremediation. J. Environ. Manage.174, 14-25.

Marchiol, L., Fellet, G., Boscutti, F., Montella, C., Mozzi, R., Guarino, G., 2013. Gentle remediation at the former "Pertusola Sud" zinc smelter: Evaluation of native species for phytoremediation purposes. Ecol. Eng. 53, 343-353.

Mcintyre, T., 2003. Phytoremediation of heavy metals from soils. Adv. Biochem. Eng. Biotechnol. 78, 97-123.

Mediouni, C., Ammar, W.B., Houlné, G., Chabouté, M.E., Jemal, F., 2009. Cadmium and copper induction of oxidative stress and antioxidative response in tomato (Solanum lycopersicon) leaves. Plant Growth Regul. 57, 89-99.

Miller, N.J., Rice-Evans, C., Davies, M.J., 1993. A new method for measuring antioxidant activity. Biochem. Soc. T. 21, 95S

Mishra, S., Jha, A.B., Dubey, R.S., 2011. Arsenite treatment induces oxidative stress, upregulates antioxidant system, and causes phytoalexin synthesis in rice seedlings. Protoplasma. 248 (3), 565-577.

Mittler, R., 2002. Oxydative stress, anti-oxidants and stress tolerance. Trends Plant Sci. 7(9), 405-410 
Quintela-Sabarís, C., Ribeiro, M. M., Poncet, B., Costa, R., Castro-Fernández, D., Fraga, M. I.,. 2012. AFLP analysis of the pseudometallophyte Cistus ladanifer: comparison with cpSSRs and exploratory genome scan to investigate loci associated to soil variables. Plant. Soil. 359, 397-413.

Pauwels, M., Saumitou-Laprade, P., Holl, A.C., Petit, D., Bonnin, I., 2005. Multiple origin of metallicolous populations of the pseudometallophyte Arabidopsis halleri (Brassicaceae) in central Europe: the cpDNA testimony. Mol. Ecol. 14, 4403-441.

Pauwels, M., Frenot, H., Bonnin, I., Saumiton-Laprade, P., 2006. A broad-scale analysis of population differentiation for $\mathrm{Zn}$ tolerance in an emerging model species for tolerance study: Arabidopsis halleri (Brassicaceae). J. Evol. Biol. 19(6), 1838-50.

Pollard, A.J., Powell, K.D., Herper, F.A., Smith, J.A.C., 2002. The genetic basis of metal hyperaccumulation in plants. Critical. Reviews in Plant Sciences. 21 (6), 539-566.

Rabier, J., Laffont-Schwob, I., Pricop. A., Ellili, A., D Enjoy-Weinkammerer, G., Salducci M.D., Prudent, P., Lotmani, B., Tonetto, A., Masotti, V., 2014. Heavy Metal and Arsenic Resistance of the Halophyte Atriplex halimus L. Along a Gradient of Contamination in a French Mediterranean Spray Zone. Water Air Soil Pollut 225 (1993), 1-16.

Rascio, N., Navari-Izzo, F., 2011. Heavy metal hyperaccumulating plants: How and why do they do it? And what makes them so interesting? Plant. Sci. 180, 169-181.

Rozpądek, P, Wężowicz, K, Stojakowska, A, Malarz, J, Surówka, E, Sobczyk, Ł, Anielska, T, Ważny, R, Miszalski, Z, Turnau, K., 2014. Mycorrhizal fungi modulate phytochemical production and antioxidant activity of Cichorium intybus L. (Asteraceae) under metal toxicity. Chemosphere. 112, 217-224.

Sakihama, Y., Cohen M.F., Grace S.C., Yamasaki H., 2002. Plant phenolic antioxidant and prooxidant activities: phenolics-induced oxidative damage mediated by metals in plants. Toxicology. 177, 67-80. 
Sarret, G., Saumitou-Laprade, P., Bert, V., Proux, O., Hazemann, J.L., Traverse, A., Marcus, M.A., Mancea, A., 2002. Forms of Zinc Accumulated in the Hyperaccumulator Arabidopsis helleri. Plant Physiol. 130, 1-12.

Schat, H., Sharma, S.S., Vooijs, R., 1997. Heavy metal-induced accumulation of free proline in a metal-tolerant and a nontolerant ecotype of Silene vulgaris. Physiol. Plant.101, 477-482.

Shah, K., Kumar, R.G., Verma S., Dubey, R.S., 2001. Effect of cadmium on lipid peroxidation, superoxide anion generation and activities of antioxidant enzymes in growing rice seedlings. Plant Scie. 161 (6), 1135-1144.

Sharma, P., Dubey, R.S., 2007. Involvement of oxidative stress and role of antioxidative defense system in growing rice seedlings exposed to toxic concentrations of aluminium. Plant. Cell. Resp. 26(11), 2027-2038.

Sharma, P., Jha, A.B., Dubey, R.S., Pessarakli, M., 2012. Reactive oxygen species, oxidative damage, and antioxidative defense mechanism in plants under stressful conditions. J. Bot. 2012, 1-26.

Sharma, S.S,. Dietz, K.J. 2006. The significance of amino acids and amino acid-derived molecules in plant responses and adaptation to heavy metal stress. J. Exp. Bot. 57:711-726.

Singh, S., Parihar, P., Singh, R., Singh, V.P., Prasad, S.M., 2016. Heavy Metal Tolerance in Plants: Role of Transcriptomics, Proteomics, Metabolomics, and Ionomics. Front. Plant. Sci. $6(1143), 1-36$.

Sytar, O., Kumar A., Latowski, D., Kuczynska, P., Strzalka, K., Prasad, M.N.V., 2013. Heavy metal-induced oxidative damage, defense reactions, and detoxification mechanisms in plants. Acta. Physiol Plant. 35, 985-999.

Szabados, L., Savouré, A., 2009. Proline a multifunctional amino acid. Trends Plant. Sci.15(2), 89-97. 
Tapia, Y., Diaz, O., Pizarro, C., Segura, R., Vines, M., Zúñiga, G., Moreno-Jiménez, E., 2013. Atriplex atacamensis and Atriplex halimus resist As contamination in Pre-Andean soils (northern Chile). Sci. Total Environ. 450-451, 188-196.

Tella, M., Auffan, M., Brousset, L., Issartel, J., Kieffer, I., Pailles, C., Morel, E., Santaella, C., Angeletti, B., Artells, E., Rose, J., Thiéry, A., Bottero, J.Y., 2014. Transfer, transformation, and impacts of ceria nanomaterials in aquatic mesocosms simulating a pond ecosystem. Environ. Sci. Technol. 48, 904-9013.

Testiati, E., Parinet, J., Massiani, C., Laffont-Schwob, I., Rabier, J., Pfeifer, H.R., Lenoble, V., Masotti, V., Prudent, P., 2013. Trace metal and metalloid contamination levels in soils and in two native plant species of a former industrial site: evaluation of the phytostabilization potential. J. Hazard. Mat. 248-249, 131-141.

Tordoff, G.M., Baker, A.J.M., Willis, A.J., 2000. Current approaches to the revegetation and reclamation of metalliferous mine wastes. Chemosphere. 41, 219-228.

Vierheilig, H., Coughlan, A.P., Wyss, U., Piché, Y., 1998. Ink and Vinegar, a Simple Staining Technique for Arbuscular-Mycorrhizal Fungi. Appl. Environ. Microbiol. 64(12), 5004-5007. Wierzbicka, M., Panufnik, D., 1998. The adaptation of Silene vulgaris to growth on a calamine waste heap (S. Poland). Environ. Pollut. 101(3), 415-426.

Zengin, F.K., 2006. The effects of $\mathrm{Co}^{2+}$ and $\mathrm{Zn}^{2+}$ on the contents of protein, abscisic acid, proline and chlorophyll in bean (Phaseolus vulgaris cv. Strike) seedlings. J. Environ. Biol. 27, 441-448. 


\section{Table captions}

Table 1: Soil trace element concentrations (means \pm standard errors) of the A. tragacantha populations of the three seed origins $(n=5)$, and for the composite soil $(n=3)$ and loam (single analysis) used for the ex situ experiment. Local background soil composition is given as a reference.

\section{Figure captions}

Fig. 1: Experimental design: The location sources of the soils and seeds are presented on a map of the south-east of France, with locations in 2 geographical areas, Bouches-du-Rhône and Var. Soils from the 3 native populations of Astragalus tragacantha i.e. Escalette (ESC), Frioul (FRI) and Var (VAR), were collected for in situ XRF analysis for trace metals and metalloids (TMM) concentrations. A polluted soil from the brownfield of Escalette (SPO) was collected for the ex situ experiment in pots, and analyzed by ICP-AES for TMM concentrations. For comparison with the polluted soil, a commercial loam (STM) was used and analyzed by XRF. The experimental design under controlled conditions at the laboratory included the seeding of seeds of the 3 population origins, either in the polluted soil or in the loamy soil. Five replicates per condition were done.

Fig. 2: Germination rate after 1 and 3 weeks of culture (A), and shoot height $(\mathrm{cm})$ after 3, 6 and 21 weeks of culture (B) of A. tragacantha in the contaminated soil (SPO) and the control (STM), depending on population. Results are expressed as means \pm standard errors $(n=5)$. Means for the same culture time followed by different letters are significantly different at $\mathrm{p} \leq 0.05$ (Dunn's test). ESC=Escalette; FRI $=$ Frioul; VAR=Var.

Fig. 3: Root length (cm) (A) and percentage of root colonization (B) by arbuscular mycorrhizal fungi (AM): mycelium \% and vesicle \% and dark septate endophytes (DSE) \% after 21 weeks of culture of $A$. tragacantha in the contaminated soil (SPO) and the control 
(STM), depending on population. Results are expressed as means \pm standard errors $(n=5)$. Means for the same parameter followed by different letters are significantly different at $\mathrm{p} \leq 0.05$ (Dunn's test). ESC=Escalette; FRI= Frioul; VAR=Var.

Fig. 4: Chlorophyll index (A), Flavonol index (B), Phenol index (C) and NBI index (D) in shoot tissues after 3,6 and 21 weeks of culture of $A$. tragacantha in the contaminated soil (SPO) and the control (STM), depending on population. Results are expressed as mean \pm standard error $(\mathrm{n}=5)$. Means for the same culture time followed by different letters are significantly different at $\mathrm{p} \leq 0.05$ (Dunn's test). $\mathrm{ESC}=$ Escalette; FRI $=$ Frioul; VAR=Var. The lowercase letters indicate statistical results for means after 3 weeks; uppercase, after 6 weeks and, italic, after 21 weeks.

Fig. 5: Stress tolerance biomarkers: Proline (A), TBARS (B) and TAOC( C) after 21 weeks of culture of A. tragacantha in the contaminated soil (SPO) and the control (STM), depending on population. Results expressed as mean \pm standard error $(n=5)$. Means for the same culture time followed by different letters are significantly different at $\mathrm{p} \leq 0.05$ (Dunn's test). $\mathrm{ESC}=$ Escalette$; \mathrm{FRI}=$ Frioul; $\mathrm{VAR}=$ Var. Lowercase and uppercase letters indicate statistical results for means of each biomarker in the shoots and in the roots, respectively.

Fig. 6: Principal component analysis of the phytometabolite and enzyme responses and root symbiont colonization in Astragalus tragacantha from the 3 populations (ESC, FRI, VAR) in the polluted (SPO) and control (STM) soils. Number following names indicates the number of weeks of growth $(3,6$ and 21$)$.

ESC: Escalette; FRI: Frioul; VAR: Var; contaminated soil (SPO) and the control (STM); NBI3, 6, 21: balance N/C after 3, 6 or 21 weeks; Flavonol 3, 6, 21: Flavonol index after 3, 6 or 21 weeks; CHL 3, 6, 21: Chlorophyll index after 3, 6 or 21 weeks; PHENOL3, 6, 21: Phenol index after 3, 6 or 21 weeks; MDA leaf: lipid peroxidation in leaves at 21 weeks; MDA root: lipid peroxidation in roots at 21 weeks; AOT leaf: antioxidant in leaves at 21 
weeks; DSE\% : percentage of dark septate endophytes; vesicle \%: percentage of AM vesicle; Mycelium \%: percentage of AM mycelium. 


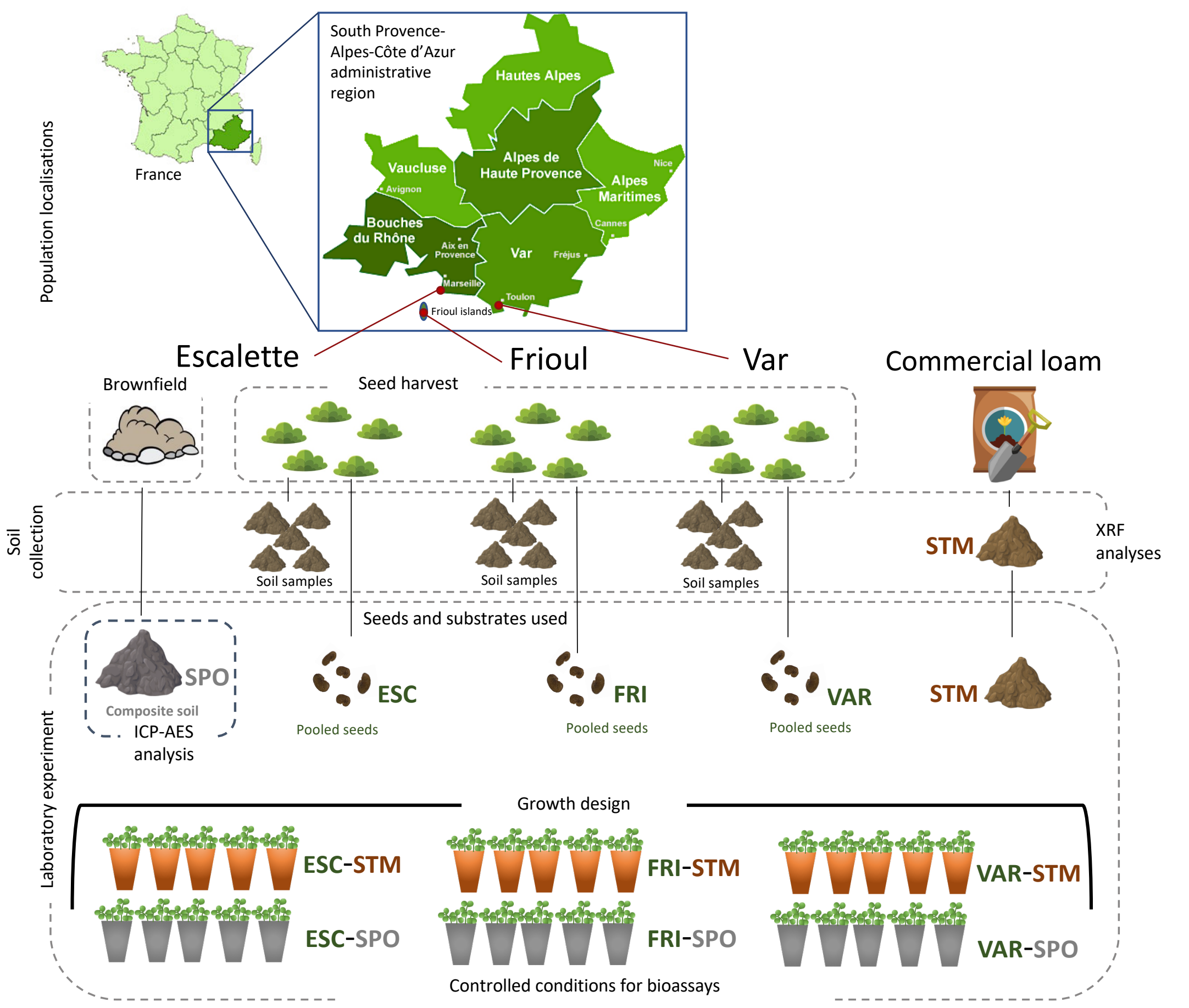




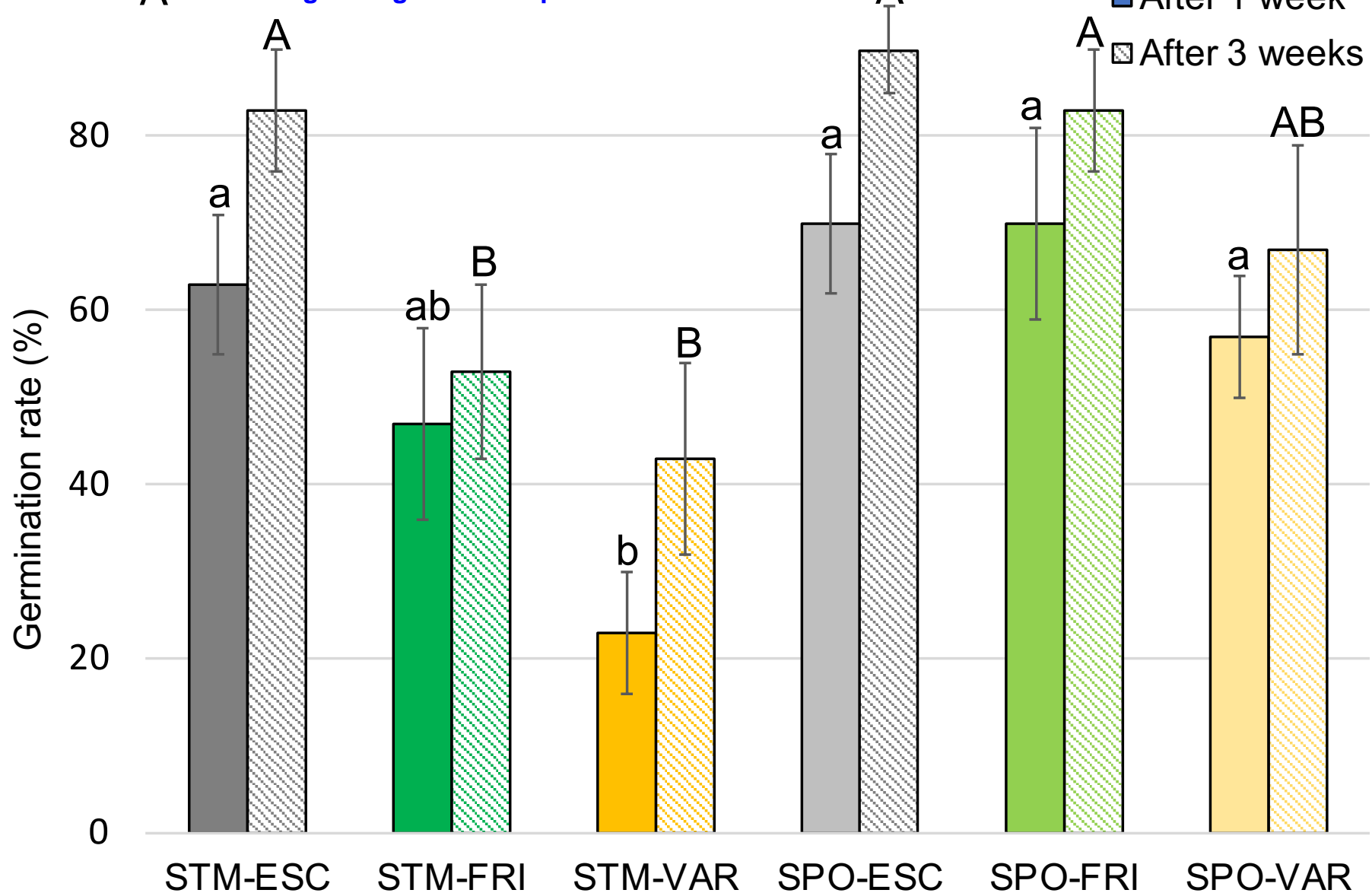
Soil treatment and seed origin

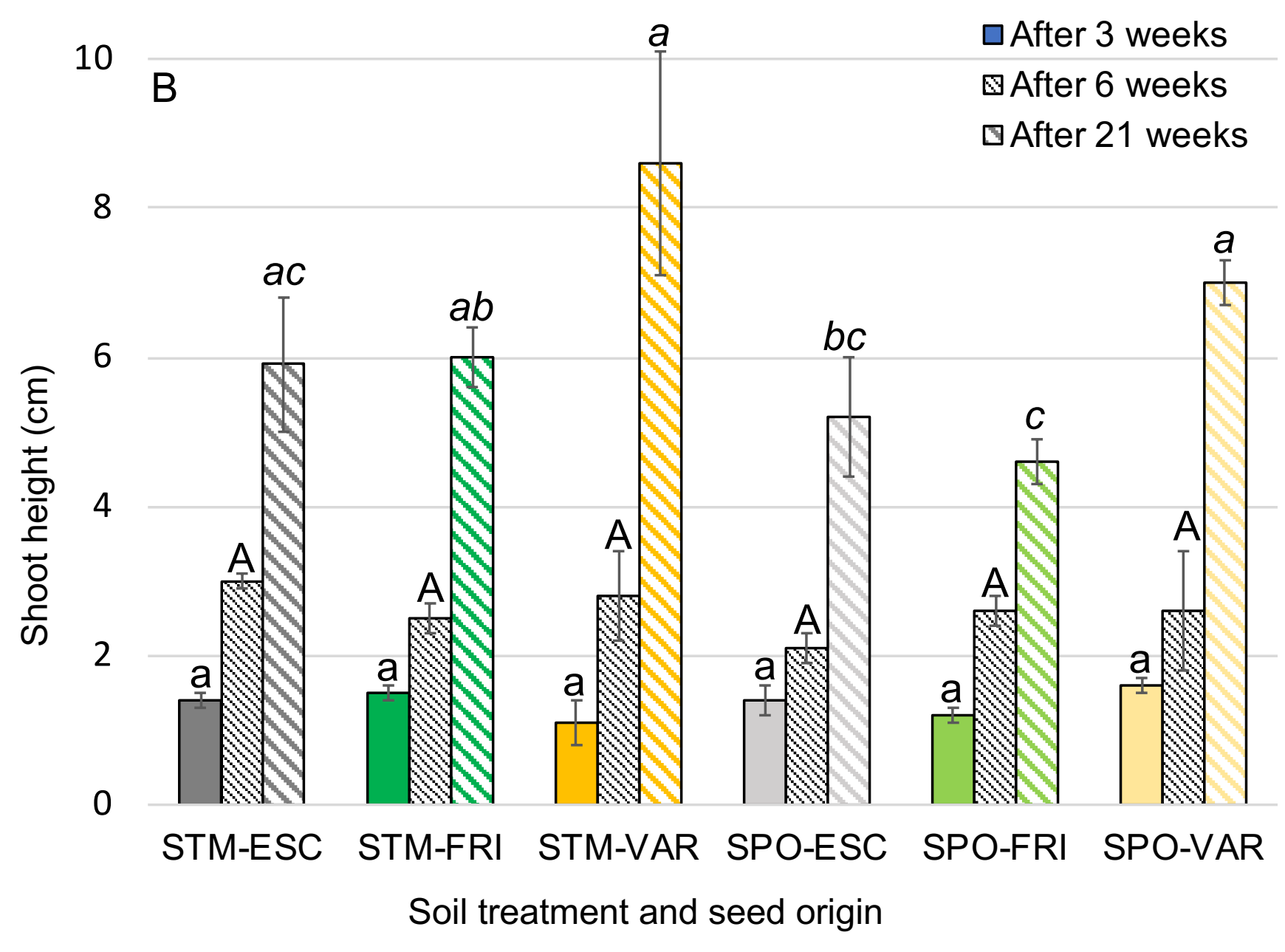




\section{Figure3}

Click here to download Figure: figure 3 - final.pdf

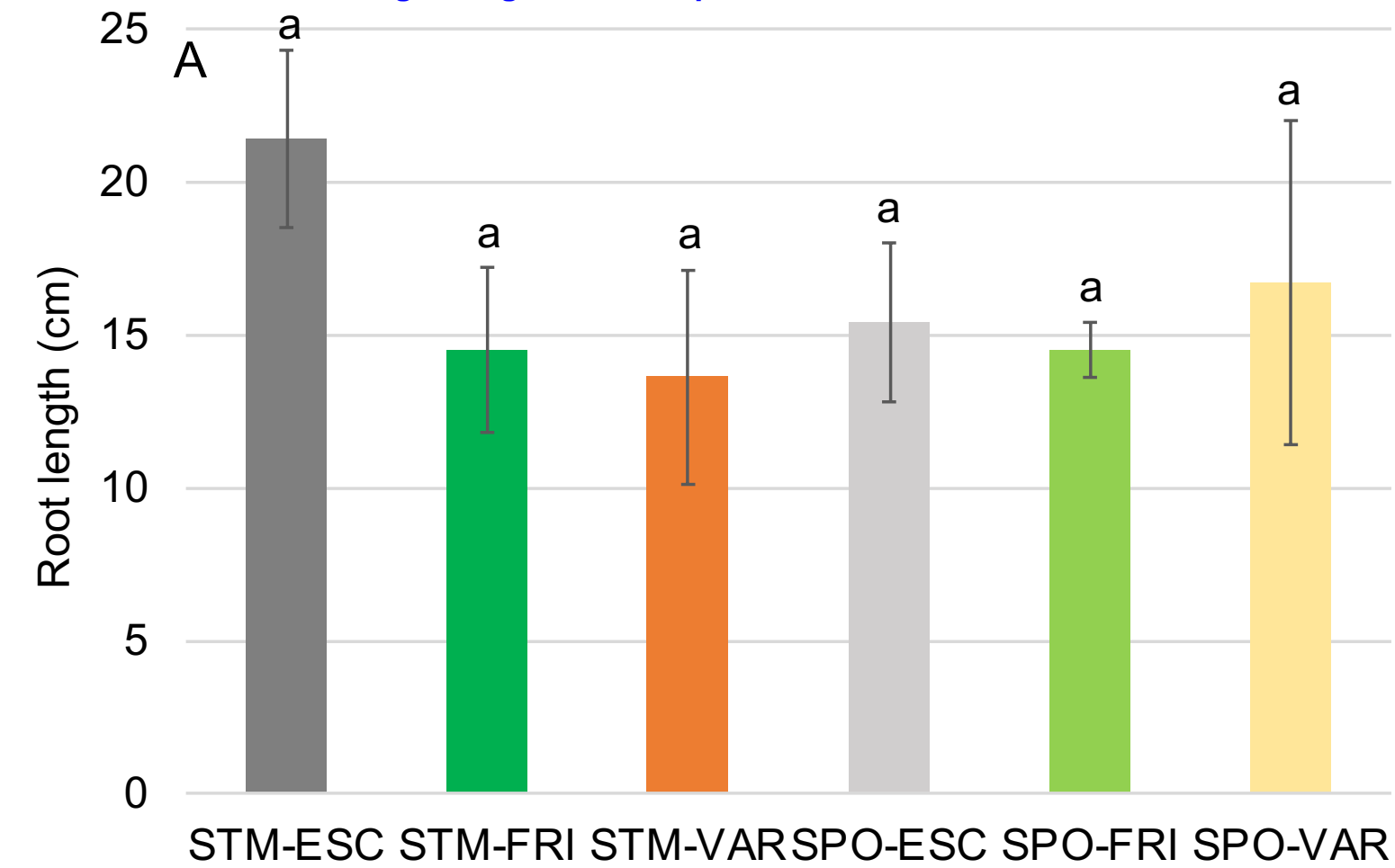

Soil treatment and seed origin

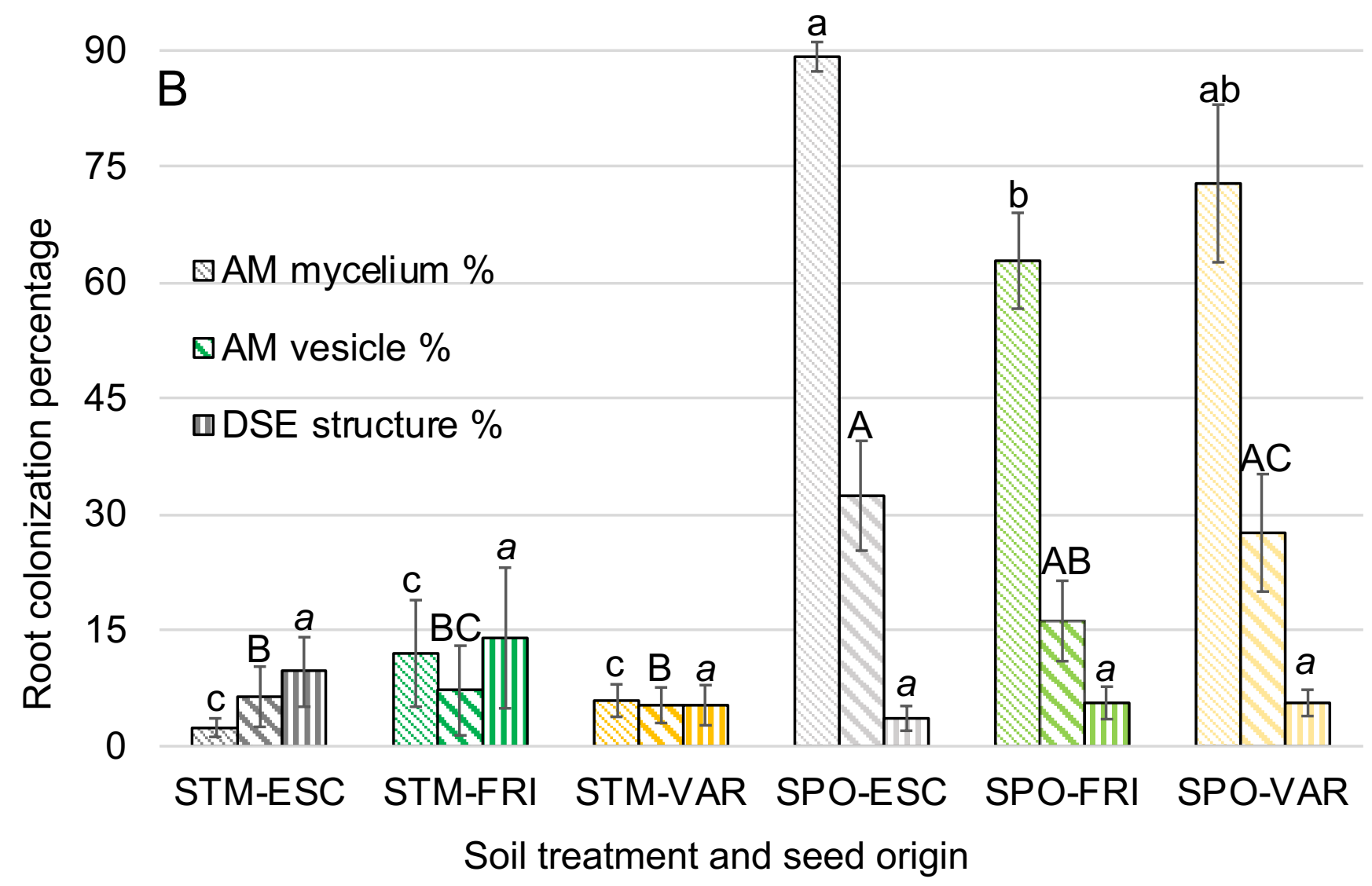

Soil treatment and seed origin 


\section{Figure4}

Click here to download Figure: Figure 4 final.pdf A

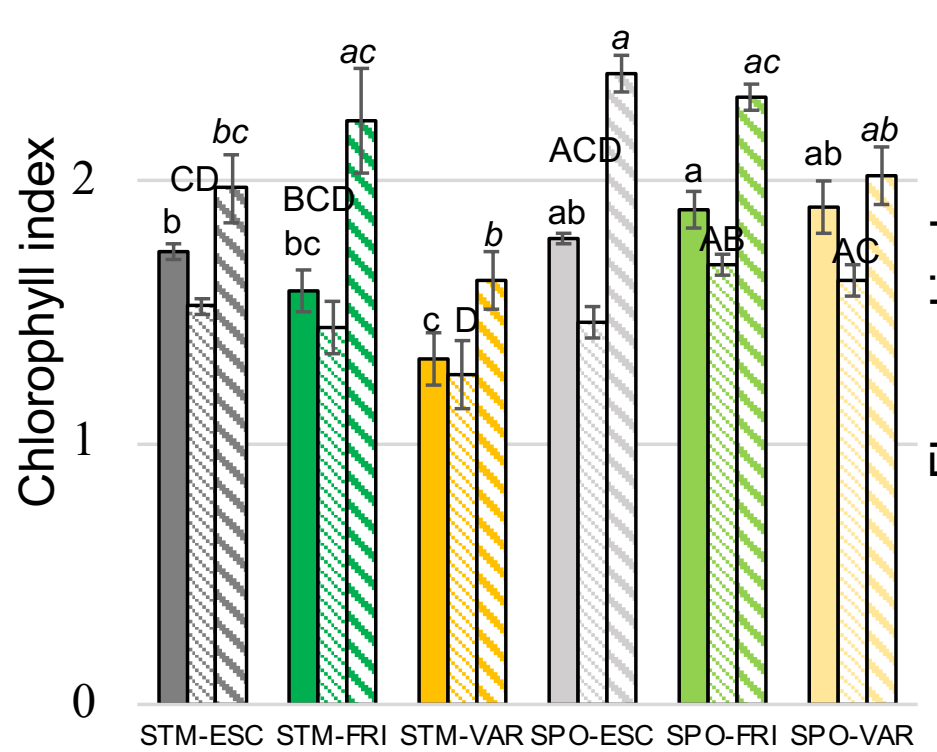$$
12
$$
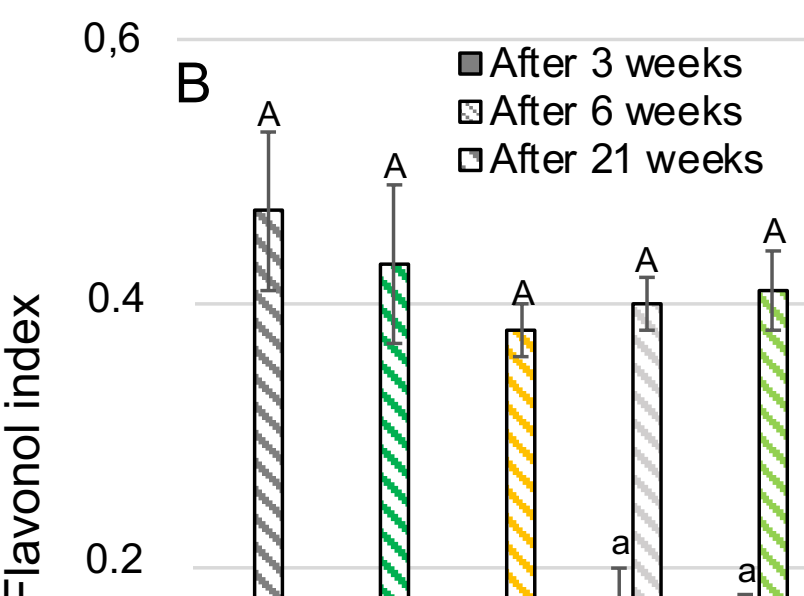

0 तो 10 मी

STM-ESC STM-FRI STM-VARSPO-ESC SPO-FRI SPO-VAR

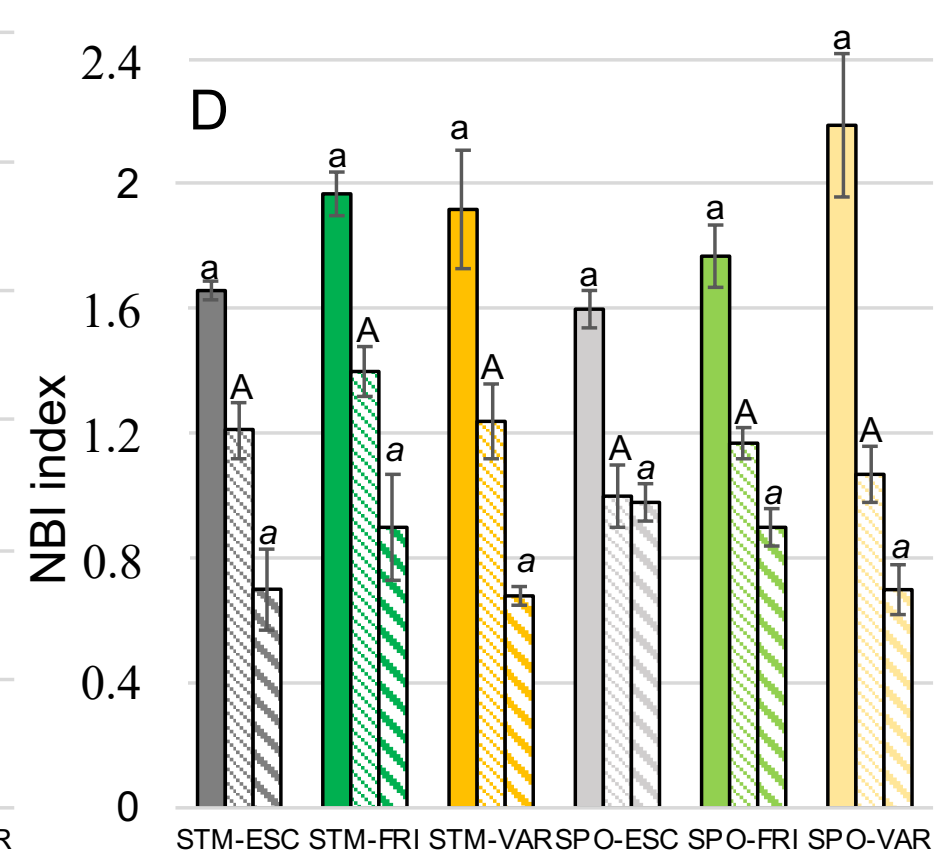

Soil treatment and seed origin 
Table 1: Soil trace element concentrations (means \pm standard errors) of the $A$. tragacantha populations of the three seed origins ( $\mathrm{n}=5$ ) and for the composite soil ( $\mathrm{n}=3$ ) and loam (single analysis) used for the ex situ experiment. Local background soil composition is given as a reference.

\begin{tabular}{|c|c|c|c|c|}
\hline Substrates & \multicolumn{4}{|c|}{ Trace metal and metalloid concentration $(\mathrm{mg} / \mathrm{kg})$} \\
\hline & $\mathrm{Pb}$ & As & $\mathrm{Cu}$ & $\mathrm{Zn}$ \\
\hline \multicolumn{5}{|l|}{$\begin{array}{l}\text { Soils from } A \text {. tragacantha } \\
\text { populations }\end{array}$} \\
\hline Frioul (FRI) & $90 \pm 37 *$ & $21 \pm 7^{*}$ & $27 \pm 5^{*}$ & $144 \pm 51 *$ \\
\hline Var (VAR) & $54 \pm 8^{*}$ & $25 \pm 1 *$ & $38 \pm 8^{*}$ & $37 \pm 2 *$ \\
\hline Escalette (ESC) & $3052 \pm 1957^{*}$ & $169 \pm 108^{*}$ & $90 \pm 53 *$ & $1660 \pm 1816^{*}$ \\
\hline Local background soil $\bullet$ & $43 \pm 17^{*}$ & $4.9 \pm 0.7 *$ & $7 \pm 3^{*}$ & $66 \pm 23 *$ \\
\hline \multicolumn{5}{|l|}{ Soils for the experiment } \\
\hline $\begin{array}{l}\text { Escalette composite soil } \\
\text { (SPO) }\end{array}$ & $9253 \pm 5540^{\star}$ & $1127 \pm 836^{\prime}$ & $32.0 \pm 4.9$ & $2698 \pm 1677$ \\
\hline Commercial loam (STM) & $49 *$ & $<\mathrm{LOD}^{*}$ & $7 *$ & $66^{*}$ \\
\hline
\end{tabular}

$\bullet$ data from previous studies (Affholder et al., 2013; Affholder et al. 2014), *XRF analysis, ${ }^{\bullet}$ ICP-AES analysis, $<$ LOD $=$ below level of detection (LOD by XRF $=9$ mg.kg-1 for As)

$\mathrm{Pb}=$ lead; $\mathrm{As}=$ arsenic; $\mathrm{Cu}=$ copper; $\mathrm{Zn}=$ zinc 